\title{
COMPARISON OF SERUM SODIUM AND SERUM POTASSIUM LEVELS AMONG SENILE CATARACT PATIENTS AND PATIENTS WITHOUT CATARACT OF SAME AGE GROUP AT A TERTIARY CARE HOSPITAL, MANDYA
}

\author{
Poornima Basavaraj ${ }^{1}$, Manjula Thamabuswamy Ramamurthy², Prathibha Shiveshi ${ }^{3}$
}

${ }^{1}$ Senior Resident, Department of Ophthalmology, Mandya Institute of Medical Sciences, Mandya, Karnataka, India.

${ }^{2}$ Professor and HOD, Department of Ophthalmology, Mandya Institute of Medical Sciences, Mandya, Karnataka, India.

3Post Graduate Student, Department of Ophthalmology, Mandya Institute of Medical Sciences, Mandya, Karnataka, India.

\section{ABSTRACT}

\section{BACKGROUND}

Previous study reports suggest an association between deranged metabolism of serum sodium and serum potassium with age related cataracts.

The present study was aimed to compare the mean serum sodium and potassium levels between the senile cataract patients and patients without senile cataract, but in the same age group.

\section{MATERIALS AND METHODS}

Case control study was carried out in a tertiary care hospital of Mandya district. A total of 120 Individuals were included, who were aged above 50 years of age, who came to our department of ophthalmology; they were divided into case group (with cataract and control group (without cataract). The mean levels of serum sodium and potassium between two groups were calculated and compared.

\section{RESULTS}

120 patients were included in the study. Out of which 60 patients belonged to cataract group (case group) and 60 patients belonged to without cataract group (control group). Mean serum sodium levels in senile cataract group (Case Group) and without cataract group (Control Group) was $140.32 \pm 3.19$ and $138.90 \pm 2.77 \mathrm{meq} / \mathrm{L}$ which was clinically significant $(0.011)$. Mean serum potassium level in cataract and without cataract group was $4.11 \pm 0.47 \mathrm{meq} / \mathrm{L}$ and $4.36+0.39 \mathrm{meq} / \mathrm{L}$ which was clinically significant (0.003).

\section{CONCLUSION}

Serum sodium level was found to be higher in case group suggesting one of the aetiopathogenesis for cataract formation. Hence higher sodium dietary intake could be a risk factor, which can be delayed with low dietary intake of sodium.

\section{KEY WORDS}

Cataract, Without Cataract, Serum Sodium, Serum Potassium.

HOW TO CITE THIS ARTICLE: Basavaraj P, Ramamurthy MT, Shiveshi P. Comparison of serum sodium and serum potassium levels among senile cataract patients and patients without cataract of same age group at a tertiary care hospital, Mandya. J. Evolution Med. Dent. Sci. 2019;8(02):111-113, DOI: 10.14260/jemds/2019/24

\section{BACKGROUND}

The crystalline lens is a transparent structure. Its transparency may be disturbed due to degenerative process leading to the opacification of lens fibres. And this development of an opacity in the lens is known as cataract.

Cataract, being the most important cause of blindness in worldwide. Up to 50 millions in the world suffer from agerelated cataract. $(1,2)$ and its prevalence in developing countries is much more increasing than the developed ones. Annual new cases of cataract in India is found to be 4 millions.(3)

'Financial or Other Competing Interest': None.

Submission 14-11-2018, Peer Review 28-12-2018,

Acceptance 04-01-2019, Published 14-01-2019.

Corresponding Author

Poornima Basavaraj,

\#304 B, Doctors Quarters,

Mandya Institute of Medical Sciences,

Mandya-571401

Karnataka,

India.

E-mail: skandaravi31@gmail.com

DOI: $10.14260 /$ jemds/2019/24

\section{(c) $(\mathbf{P}) \ominus$}

Multiple mechanisms are involved as such osmotic graduation, protein aggregates, oxidative stress, post translational protein changes, phase separation which are proposed for cataract formation, though the exact pathogenesis is not yet known.(4-10) Several other risk factors are the reason for the development of cataract in which one is found to be the serum sodium levels in the cataract patients lens which has the ion pump mechanism is not only applicable for the lens matter but is also related to the serum or plasma level of serum sodium and serum potassium i.e, normal lens has the $\mathrm{Na}+-\mathrm{K}+$ ATPase pump which keeps the ion in balance.(11-12) Hence increase in serum sodium and decrease in serum potassium level can lead to cataract formation.

Given the extend of disability caused by cataract formation it is important that some measures to be taken to slow down the development of the cataract, as we cannot prevent it from occurring. A delay in cataract formation for 10 years will reduce the prevalence of cataract by $50 \%$, such delay will enhance the quality of the life for much of the older population and reduces the economic burden due to visual disability and surgery. ${ }^{(13)}$

Several earlier studies have showed that the nutritional factor is been a risk factor for development of cataract in 
particular increased intake of the dietary sodium i.e., elevated serum sodium being a risk factor. Hence the prevention of excess dietary intake may delay the progression of cataract.(14-16)

So, the present study was aimed to evaluate the serum sodium and serum potassium level between two groups of cataract and without cataract of same age group.

\section{MATERIALS AND METHODS}

A case control study was carried out during a period of three months i.e., May 2017 to July 2017. And the study was conducted after obtaining approval from the Institutional Ethics Committee, department of Ophthalmology, MIMS, Mandya. A total of 120 Patients (60 patients as case group and 60 patients as control group) were included, who came for ophthalmic evaluation. These two group as case group and control group) of same age group. Patients with hypertension, diabetes and any other systemic disorders were excluded. Patients on examination with other causes of cataract like post inflammation, steroid induced, traumatic and retinal pathology and any other pathology were dropped out of study. Detailed anterior and posterior, retinal examination was carried out. Later grading of cataract done using LOCS II classification. Then a fasting-state blood sample was obtained from both case group and control group and sent to the laboratory by drawing $2 \mathrm{ml}$ of blood taken under aseptic precautions. Serum sodium and serum potassium level were measured with flame photometry method. The normal reference of serum sodium and serum potassium level for analysis used were 130-143 meq/L and 3.5-5.5 $\mathrm{meq} / \mathrm{L}$.

Sample size was taken for convenience.

\section{Group 1 (Case Group)}

Senile cataract (Nuclear/cortical/posterior subcapsular cataract) patients, who were posted for cataract surgery.

\section{Group 2 (Control Group)}

Senile normal healthy individuals without cataract, who were came to OPD for routine check-up with same age and sex matched with group 1.

\section{Statistical Methods}

Descriptive and inferential statistical analysis has been carried out in the present study. Results on continuous measurements are presented on Mean \pm SD (Min-Max) and results on categorical measurements are presented in Number (\%). Significance is assessed at $5 \%$ level of significance.

Student $\mathrm{t}$ test (Two tailed, independent) has been used to find the significance of study

\section{RESULTS}

In this study a total of 120 individuals were included, out of which the case group consisted of 60 patients with senile cataract and other 60 patients without cataract of same age group. Control group and case group were taken in the same age and sex group. The mean age for case group was $60.80 \pm$ 8.45 year and that of control group was found to be $59.00 \pm$ 6.75 year.
The mean serum sodium levels among case group and control group were found to be with the mean serum sodium levels to be higher in case group $140.32 \pm 3.19$ meq/L compared to control group(table-1) and the difference was moderately statistically significant in case group $(138.90 \pm$ $2.77 \mathrm{meq} / \mathrm{L}$ (p-Value 0.011).

The mean serum potassium levels among case group and control group were found to be with the mean serum potassium levels to be lower in case group $4.11 \pm 0.47 \mathrm{meq} / \mathrm{L}$ compared to $4.36 \pm 0.39 \mathrm{meq} / \mathrm{L}$ control group and the difference was statistically significant in case group ( $p$-Value 0.003)

These above results are not same as previous studies, the serum sodium level with moderate significance shown the variable results whereas the serum potassium levels showed the similar significance with the previous studies results. $(17,18,19)$

\begin{tabular}{|c|c|c|c|}
\hline Serum Cations & $\begin{array}{c}\text { Case } \\
\text { (Cataract) }\end{array}$ & $\begin{array}{c}\text { Control } \\
\text { (No Cataract) }\end{array}$ & p-Value \\
\hline $\begin{array}{c}\text { Serum Sodium } \\
(\mathrm{mEq} / \mathrm{l})\end{array}$ & $140.32 \pm 3.19$ & $138.90 \pm 2.77$ & $0.011^{*}$ \\
\hline $\begin{array}{c}\text { Serum Potassium } \\
(\mathrm{mEq} / \mathrm{l})\end{array}$ & $4.11 \pm 0.47$ & $4.36 \pm 0.39$ & $0.003^{* *}$ \\
\hline \multicolumn{4}{|c|}{ Table 1. Comparison of Serum Sodium and Potassium } \\
Levels
\end{tabular}

\section{DISCUSSION}

There have been various models describing the multiple risk factors involved in cataract development. Despite the complexity of identifying cataract risk factors, attempt should be provided with new hopes in dealing with morbidity of cataract and the cost of disease.

David Maurice 25 years ago, discussed the togetherness with the cell-to-cell movement of ions which is facilitated by extensive coupling in the lens cell mass. The expression of different $\mathrm{Na}$, K-ATPase and Ca-ATPase isoforms in lens epithelium and fiber cells is considered along with mechanisms that potentially regulate the activity of these transport proteins.(20)

The main aim of the present study was to find the significant difference between serum sodium and serum potassium levels in individuals with cataract and without cataract of same age group.

Comparison of the means of serum sodium and potassium among cases and controls indicated significantly high levels of serum sodium in blood of cataract patients as compared to their controls.

Earlier previous studies have shown the results different for serum potassium levels whereas the levels of serum sodium have found to be consistent.(21)

Zil'fian et al, studies showed the mechanism of balance of ion exchange within the lens and its disturbance in formation of cataract. (22)

Gaurav Mathur et al, study showed increase in serum sodium level with statistically significant with insignificant serum potassium levels.

Hence by the above discussion it holds that any change in the ion exchange pump mechanism is the pathogenesis for cataract formation which can be directly related to the nutritional status of the person. As we know, high level of serum sodium in turn leads to cataract formation.(23) 


\section{CONCLUSION}

According to this study, the serum sodium levels were found to be higher in case group when compared to control group and its reduction in diet may delay the formation of the cataract. Hence serum sodium may be considered as one of the risk factor for cataract pathogenesis. Where increase in dietary intake of serum sodium can be directly affected with ion exchange pump mechanism in the lens and anterior chamber leading to cataract formation. Further studies are required to support these findings and larger number of patients are required for accurate statistical findings.

\section{REFERENCES}

[1] Bunce GE, Kinoshita J, Horwitz J. Nutritional factors in cataract. Annual Review of Nutrition 1990;10:233-54.

[2] Sperduto RD. Epidemiological aspects of age related cataract. In: Tasman W, Jaeger A, eds. Duane's Clinical Ophthalmology. Philadelphia: Lippincott-Raven Publishers 2000: p. 12-4.

[3] Delamere NA, Paterson CA. Crystalline lens. In: Tasman W, Jeager A, eds. Duane's Foundations of clinical ophthalmology. $5^{\text {th }}$ edn. Philadelphia: Lippincott-Raven Publishers 2001: p. 5-11.

[4] Duncan G, Bushell AR. Ion analysis of human cataractous lenses. Experimental Eye Research 1975;20(3):223-30.

[5] Duncan G, Bushell AR. Relationships between colour, $\mathrm{Na}^{+}$, protein content in individual senile human cataract lens. Ophthalmic Research 1980;11:379-83.

[6] Kupfer C. Bowman Lecture. The conquest of cataract: a global challenge. Trans Ophthalmology Society 1984;104:1-10.

[7] Diplock AT, Charleux JL, Crozier-Willi G, et al. Function of food science and defence against reactive oxidative species. British Journal of Nutrition 1998;80(Suppl 1):S77-S112.

[8] Machlin LJ, Bendich A. Free radical tissue damage: protective role of antioxidant nutrients. Journal of Federation of American Societies for Experimental Biology 1987;9:444-5.

[9] Jacob RA, Burri BJ. Oxidative damage and defence. American Journal of Clinical Nutrition 1996;63(6):985S-90S.

[10] Clayton RM, Cuthbert J, Duffy J, et al. Some risk factor associated with cataract in S.E. Scotland: a pilot study. Trans Ophthalmol Soc U K 1982;(102 Pt 3):331-6.
[11] Sperduto RD, Hiller R. The prevalence of nuclear, cortical and posterior sub-capsular lens opacities in a general population sample. Ophthalmology 1984;91(7):815-8.

[12] Clayton RM, Cuthbert J, Phillips CI, et al. Analysis of individual cataract patients and their lenses: a progress report. Experimental Eye Research 1980;31(5):533-66.

[13] Balasubramanian D, Bansal AK, Basti S, et al. The biology of cataract. The Hyderabad Cataract Research Group. Indian J Ophthalmol 1993;41(4):153-71.

[14] Mirsamadi M, Nourmohammadi I, Imamian $M$. Comparative study of serum $\mathrm{Na}+$ and $\mathrm{K}+$ levels in senile cataract patients and normal individuals. Int J Med Sci 2004;1(3):165-9.

[15] Mathur G, Pai V. Comparison of serum sodium and potassium levels in patients with senile cataract and age-matched individuals without cataract. Indian Journal of Ophthalmology 2016;64(6):446-7.

[16] Deokar SA, Rai PS, Ingale PW, et al. Study of serum sodium and potassium concentration in cataract patients. Int J Res Med Sci 2014;2(2):592-4.

[17] Donnelly CA, Seth J, Clayton RM, et al. Some blood plasma constituents correlate with human cataract. $\mathrm{Br}$ J Ophthalmol 1995;79(11):1036-41.

[18] Nourmohammadi I, Gohari L, Moddares M, et al. Evaluation of erythrocyte glutathion peroxidase, superoxide dismutase and total antioxidants in cataract patients. Arch Iran Med 2001;4:123-7.

[19] The Italian-American Cataract Study Group. Risk factors for age-related cortical, nuclear and posterior subcapsular cataracts. Am J Epidemiol 1991;133(6):541-53.

[20] Paterson CA, Delamere NA. ATPases and lens ion balance. Exp Eye Res 2004;78(3):699-703.

[21] Cumming RG, Mitchell P, Smith W. Dietary sodium intake and cataract: The Blue Mountains Eye Study. Am J Epidemiology 2000;151(6):624-6.

[22] Zil'fian AA. Disorders of ion balance in intraocular liquid at patients with senile and complicated cataracts. Georgian Med News 2013;(218):10-5.

[23] Phillips CI. Cataract: a search for associated or causative factors. Excerpta Med 1980;34:19-25. 